\title{
Babel Syndrome and the New Security Doctrine of the United States ${ }^{1}$
}

\author{
José Luís Fiori \\ Professor of International Political Economy at the Federal University of Rio de Janeiro; Director of the 'Ethics and Global \\ Power' and 'Global Power and the Geopolitics of Capitalism' research groups; Fellow of the Institute for Strategic Studies \\ on Oil, Gas, and Biofuels; jlfiori@uol.com.br
}

\begin{abstract}
This article explores the significance to the inter-state capitalist system of the new US national security strategy, as defined by the Donald Trump administration on 17 December 2017. By looking beyond the inconsistencies and idiosyncrasies of President Trump, we see that this strategy represents a break, not only with the strategies of recent US administrations but also with a longer tradition in US foreign policy. This article proposes that the supposed crisis of 'liberal order' is a direct and inevitable result of the expansion and success of the inter-state capitalist system. To explain the strategy of the US in this scenario, the article adopts an unorthodox approach, analysing the myth of the Tower of Babel.
\end{abstract}

Keywords: crisis of liberal order, inter-state capitalist system, principled realism, security strategy, Tower of Babel

This strategy is guided by principled realism. It is realist because it acknowledges the central role of power in international politics, affirms that sovereign states are the best hope for a peaceful world, and clearly defines our national interests... We are also realistic and understand that the American way of life cannot be imposed upon others, nor is it the inevitable culmination of progress.

The White House, 'National Security Strategy of the United States of America' (The White House, 2017)

The White House published the new 'National Security Strategy of the United States of America' at the end of 2017, as the first year of President Donald Trump's mandate was coming to an end (The White House, 2017). It is a broad declaration, which defines the principal interests of the US and the actions that will be undertaken to protect national security against every kind of threat, from all over the world. It would be a mistake to treat this as just one more periodic document produced for bureaucratic purposes. The strategy was developed by the State Department, together with the Pentagon, the CIA and other security and intelligence organs of the US government, as well as the Department of Commerce and the Department of the Treasury.
To grasp its importance, it is necessary to distinguish it from the eccentric and unpredictable character of Donald Trump. But it is also necessary to recognise that it would take a character like Trump to bring about such a break from the history and tradition of US foreign policy.

From a strictly academic perspective, the new strategy document looks like an applied manual of realist theory. It defines strategic objectives and identifies the main rivals of the US, collectively considered to present a threat to the country's national interests. It sets out four 'vital national interests', which are not fundamentally new (ibid.: 3): 1) the protection of the American people and their way of life; 2) the promotion of economic prosperity and America's technological leadership; 3) the preservation through force of world peace; 4 ) the expansion of the global influence of the US. The strategy then identifies the threats to American national interests (ibid.: 25-6): 1) Russia and China, the two great 'revisionist powers'; 2) North Korea and Iran, two 'rogue states' that undermine geopolitical equilibrium in Northeast Asia and the Middle East; 3) 'Jihadist terrorist groups' and international criminal organisations that propagate violence and traffic drugs and arms.

The document offers an extensive list of actions to be undertaken by the US to achieve strategic objectives and 
confront rivals, from controlling borders to increasing military expenditure and protecting competitive advantages in the development of technologies critical to economic growth and security; from controlling the production and distribution of energy to combating corruption.

But the novelty of the new security strategy does not lie in any of these particular details, variations of which have appeared repeatedly in other documents, in previous decades. Rather, it can be found in various premises that inform the strategy and are presented as if they were conventions of the American foreign-policy establishment, when in fact they collectively represent a break with a basic consensus on American exceptionality that previously united American elites. It is possible to list the main premises synthetically, without necessarily following the order of their presentation in the strategy:

1 the international system is a space of permanent competition for power between sovereign states, which are responsible for the construction of a peaceful world order;

2 the world is made up of strong, independent and sovereign nations, with their own cultures, values, ideas and dreams;

3 American values are not universal and, though they should not be compromised, there is no guarantee that they can be universalised through the expansion of markets and democracy;

4 all foreign-policy decisions of the US government must be based on national interest and taken from a position of power - the US must not be an arbiter of conflicts around the world;

5 to maintain its position of power, the US must reassume global leadership in processes of technological innovation, particularly in relation to war technologies;

6 economic prosperity is an instrument for the projection of the global power of the US;

7 the US must abandon its attempts at ethical and cultural hegemony, pursuing its interests using force throughout the world;

8 there are no longer absolute enemies: negotiations are possible with everyone and must be conducted according to the rational pursuit of American advantage.

These premises are not simply Trumpian idiosyncrasies. On the contrary, they emerge collectively from a long battle within the American establishment, in which the military has, for the time being, gained the upper hand over civil servants and career politicians, with their cosmopolitan project of liberal order and rules-based global governance, initiated after the Second World War and expanded after the Cold War. If this victory is consolidated, it will bring an end to the American messianism of the twentieth century, with its division of the world between 'good' and 'evil', its globalising imperative to reorganise the world through the deregulation of markets and frontiers and its conceited attempts to universalise liberal democracy and human rights. And it will also pose an existential threat to liberal humanitarian institutions, which have depended on the financial and political capital of the US.

Far from promoting a final and permanent peace, the new security strategy situates the US in an inter-state system in which war is possible at any time, in any location, with any rival, enemy or former ally. How might we explain this apparent shift in American strategy?

A growing number of analysts, particularly North Americans, consider that we are seeing the end of the post-war liberal order. And they attribute liberal crisis to two fundamental factors: 1) the frustration of a significant part of American and European society with the results of economic globalisation; 2) the growing challenge to Western hegemony, primarily from China. Our suggestion here, however, points in the opposite direction: that the supposed crisis of 'liberal order' is a direct and inevitable result of the expansion and success of the inter-state capitalist system.

To explore this proposition, let us adopt an approach that is highly unorthodox in the field of international political theory: the analysis of myths. ${ }^{2}$ We will focus here on an interpretation of a millenarian religious myth, universalised through the Judeo-Christian tradition: the myth of the Tower of Babel. Ancient and enigmatic, this myth appears in almost identical form in different places and cultures throughout the history of Mesopotamia. As with all myths that have resisted the passing of time, this one contains truths and lessons that transcend the time and place of its creation and even transcend its original religious function. This is certainly the case with the Judeo-Christian version of the myth of Babel. ${ }^{3}$ Set in an imaginary context, it describes a universal 'syndrome' of the struggle for power. It is suggestive for those who seek to explain recent changes in international relations and in the security strategy of the US.

According to the myth of the Tower of Babel, humanity, after the Great Flood, was united and spoke just one language and had just one system of values. It sought to build a tower to reach heaven. But God, taking this as a challenge to his exclusive authority, divided humanity, scattering people and giving each nation a different tongue and a different system of values so that they would not understand each other, nor develop their power collectively. Later, compromising his 'universality', God chose one people to carry out his designs, to be the instrument of his will and to wage wars against all the peoples he had created and dispersed across the earth. 
Our hypothesis here, then, is that since the end of the Cold War, something comparable has occurred in the inter-state system. 'Babel syndrome' has determined the course of international relations for almost three decades, and the story has now reached its climax. Let us explain further.

The basic unit of power in the world system in which we live at the beginning of the twenty-first century is still the nation state, with its frontiers clearly delimited and its sovereignty recognised by other members of the system. This inter-state system was formed in Europe, during what Fernand Braudel called the 'long sixteenth century' (1450-1650), and it has since expanded continuously inside and outside Europe, with particularly important 'waves' during the nineteenth century and the second half of the twentieth century. Throughout this period, the European state system has conquered and incorporated other continental territories, empires and peoples, which, bit by bit, have adopted the rules of coexistence established by the Peace of Westphalia, declared in 1648, at the end of the Thirty Years War.

The Peace of Westphalia was signed by approximately 150 European 'territorial authorities', but at that time there were only six or seven modern states. After the Napoleonic Wars, at the beginning of the imperialist age' (1840-1914), this number increased due to the independence of American states, and at the end of the Second World War the UN Charter was signed by 50 independent states.

It was in the second half of the twentieth century that the inter-state system expanded more rapidly. Today there are almost 200 sovereign states with a seat at the UN. Decolonisation and the independence of African and Asian states contributed to this expansion. And of particular importance was China's transformation of its ancient civilisation and empire into a nation state, which, after the Cold War, would sign up to the international institutions and regulations created following the Second World War. Indeed, this is one of the reasons that, in the 1990s, American commentators referred to the 'end of history', the emergence of a unipolar world, the victory of Western liberalism and the universalisation of Western values.

And they were right, to the extent that the US achieved a global power without precedent in human history, accelerating the globalisation of the inter-state capitalist system and the rules and institutions of the post-war liberal order. But, at the same time, the expansion of American power was itself decisive in the (military) resurgence of Russia and the economic growth of China - two powers that began to use the very rules and institutions of liberal order to challenge American hegemony and destabilise the notion of unipolarity. And Iran, Turkey, North Korea and various other countries today use 'Westphalian diplomacy' and the 'geopolitics of nations' - European inventions - to question the hierarchy of this European system led by the US.

From our point of view, it was exactly this convergence and normative homogenisation in the inter-state system, on the one hand, and the increasing power of states that question American exceptionality and centrality using rules authored by the US itself, on the other, that began to threaten the global power of the US. This obliged the US to make an about-turn, responding in accordance with 'Babel syndrome'.

Challenged on its own terms, the US disavows its moral universalism within the inter-state system and desists from the old enlightenment project of conversion of all the peoples of the world to Western reason and ethics. At the same time, it gives up its role as guardian of international ethics and arbiter of all the world's conflicts. This does not mean that it stops projecting the superiority of its national values, but, acting as a nation of 'chosen people', it opts for the unilateral exercise of its power, through force and the active division and dispersion of its competitors, boycotting every kind of multilateral or regional agreement or bloc, from the European Union to UNASUR, from NAFTA to the BRICS.

Can this new American strategy be reversed? It is difficult to tell, but it is important to understand that it didn't come from nowhere, nor is it the exclusive work of President Trump. The polarisation of American society and the internal divisions within the American establishment will likely increase in the coming years, but it is unlikely that this will shift the strategic direction of the US, nor hinder the expansion of its military power. Such an internal struggle is not exceptional; there were others at various moments during the twentieth century, every time it was necessary to respond to crucial challenges in the international arena. And the same can be said of the 'cyclothymia' of American analysts, who celebrated the end of the Second World War and the victory of the democratic world and then became depressed, speaking of the end of American hegemony in the 1970s and 1980s; they then celebrated again at the end of the Cold War, with the apotheosis of liberal order, and have now become depressed again, speaking of the end of this same order and declining American power. And it is most likely that they are wrong again.

International politics is going through a moment of great instability and accelerated transformation. But with this moment placed in a broad historical context, in which the inter-state capitalist system expands continuously, the great powers that lead this expansion, including the US, can be seen to act in a more or less predictable way:

In the relationship between nation states, the mere preservation of social existence requires the constant 
expansion of power because, in a situation of open competition, those who do not rise, fall. In other words, in the inter-state system, every great power is obliged to expand its power continuously, even in periods of peace, if possible seeking the limit of absolute and global monopoly. But reaching this limit is an impossibility in this system because, if it were to be reached, the system would disintegrate.

To be more precise: The constitution of a global empire would always result from the victory of a specific nation state - a state capable of monopolising power to the extent that its rivals disappear. However, if this were to happen, the victorious state would not be able to continue increasing its own power since the mechanism for the accumulation of power - competition - would no longer exist. It is this mechanism that causes the disorderly and uneven, but continuous, expansion of the inter-state system itself.

For this very reason, war and preparation for war do not preclude co-existence, complementarity, and even alliances between states. At times, conflict predominates, at times complementarity. But it is this dialectic that allows for the existence of periods of peace within the inter-state system, which nonetheless do not interrupt competition nor eradicate latent conflict between the most powerful states.

The hegemon must continue expanding its power to maintain its relative position. And its accumulation of power, as with that of the other states, depends on preparation for war against real or virtual enemies, which are created by the contradictions of the system. The disappearance of competition would lead to the hegemon - and indeed other states - losing power and the system would face 'entropic homogenisation'. Contrary to the propositions of hegemonic stability theory, it is impossible for the leading power to stabilise the system. Competing and warring to expand, the hegemon often must destroy the very rules and institutions it authored, usually after a great military victory.

As such, the system should be thought of as a 'universe in expansion', in which there never will be 'perpetual peace', nor 'hegemonic utopia'. It is a universe that requires war and crisis to order and 'stabilise' - always in a transitory way - and sustain its necessarily hierarchical structures.

(Fiori, 2008: 29-30)

Those analysts who now announce the end of liberal order tend to predict a great confrontation between the Chinese hierarchical system, based on tributary relations, and the Westphalian system, based on national sovereignty. But it is more likely that the world system will go through a prolonged period of turbulence and wars provoked by sudden changes and increasingly unstable alliances, precisely because it is reproducing the history of the formation of the European state system on a planetary scale.

\section{Notes}

1 Translated from Portugese by Juliano Fiori.

2 In the psychological and psychoanalytical theories of Sigmund Freud and Carl Jung, as in the structural anthropology of Claude Lévi-Strauss, mythology occupies a central place in the history of human thought and in the cultural expressions of great civilisations, because it synthesises, symbolically, thoughts and truths that transcend space and time.

3 'And the Lord said, Behold, the people is one, and they have all one language; and this they begin to do: and now nothing will be restrained from them, which they have imagined to do. Go to, let us go down, and there confound their language, that they may not understand one another's speech. So the Lord scattered them abroad from thence upon the face of all the earth: and they left off to build the city. Therefore is the name of it called Babel; because the Lord did there confound the language of all the earth: and from thence did the Lord scatter them abroad upon the face of all the earth.' (King James Version, Genesis 11.5-9)

\section{Bibliography}

Fiori, J. L. (2008), 'O sistema interestatal capitalista no início do século XXI', in Fiori, J. L., Medeiros, C. and Serrano, F. (eds), O Mito do Colapso do Poder Americano (Rio de Janeiro: Editora Record), pp. 173-277.

The Holy Bible, King James Version (1991) (Glasgow: Harper Collins). The White House (2017), National Security Strategy of the United States of America 2017 (Washington: The White House). 